\title{
Comparative Soil Nutrient Status and Microbiota Associated in the Rhizosphere of Oroxylum indicum growing in Different Natural Habitat in North East India
}

\author{
Chandrima Debi ${ }^{1 *}$ and Vipin Parkash ${ }^{2}$ \\ ${ }^{1}$ Forest Research Institute (Deemed) University, India \\ ${ }^{2}$ Forest Pathology Division, Forest Research Institute (ICFRE), \\ Dehradun-248195, Uttrakhand, India \\ *Corresponding author
}

\begin{abstract}
Keywords
Oroxylum indicum,

Microbiota,

Trichoderma

harzianum,

Pseudomonas sp.,

Soil nutrient status.

Article Info

Accepted:

19 October 2017

Available Online:

10 December 2017 where Oroxylum indicum was naturally growing in its ecological habitat and were analysed. A total of 25 fungal species and four bacterial isolates were found to be associated in the rhizosphere of O.indicum. The fungal microbiota comprised mainly of Trichoderma harzianum, Penicillium sp., Aspergillus sp., Trichoderma viride, Fusarium sp., Penicillium funiculosum, Penicillium capsulatum, Penicillium citrinum, Pachybasium sp., Trichoderma hamatum, Mucor sp., Verticillium sp., Curvularia sp., Rhizomucor sp., Pythium sp., Rhizoctonia sp., Colletrotrichum sp. etc. While the bacterial isolates mainly comprised of Four bacterial isolates Pseudomonas putida, Pseudomonas sp., Streptobacillus sp., Bacillus sp. The overall analysis of soil nutrient status showed that $\mathrm{pH}$ status was higher in roadside and riverside, while mimum $\mathrm{pH}$ was found in forest fringe and hillslope. The \% Organic Carbon was found to be highest in agricultural farmland and lowest in hillslope. Available Nitrogen was highest in agricultural farmland, while it was minimum in forest fringe. Available Phosphorus was again highest in agricultural farmland while it was lowest in riverside and forest fringe areas. Available Potassium was highest in hillslopes and agricultural farmland while it was lowest along riverside.
\end{abstract}

\section{A B S T R A C T}

The rhizospheric soil samples were collected from five different sites of Northeast India

\section{Introduction}

The rhizosphere is a densely populated area in which the roots must compete with the invading root systems of neighboring plant species for space, water and mineral nutrients, and with soil-borne microorganisms, including bacteria, fungi, and insects feeding on an abundant source of organic material (Ryan and Delhaize 2001). Soil acts as a habitat for diverse group of microorganisms. Plant root exudates enrich rhizosphere region of the soil and attracts a variety of micro-organisms. Plant growth is influenced by the presence of bacteria and fungi and their interactions are common in the rhizospheres of plants with high relative densities of microbes (Berg and Smalla, 2009). Rhizosphere interactions are not solely driven by roots but are highly integrated with and influenced by residing organisms and local edaphic factors. Soil-inhabiting mutualists and parasites, both prokaryotic and eukaryotic, are actively involved in signaling 
with a host plant. Microbial populations react to the exudates released by plant roots making the rhizosphere interactions very dynamic which are altered by addition or loss of any microbe (Badri et al., 2009). A strong interaction prevails between the group of microorganisms colonising the rhizosphere region and plant roots. Microorganisms and their products also affect the roots in a variety of positive, negative and neutral ways (Broeckling et al., 2008).

Plant growth-promoting bacteria occupy the rhizosphere of many plant species and have beneficial effects on the host plant. They may influence the plant in a direct or indirect manner. A direct mechanism would be to increase plant growth by supplying the plant with nutrients and hormones. The release of carbon compounds from plants into the rhizosphere increases microbial biomass and activity. Pseudomonas sp. comprises a genus of ubiquitous Gram-negative bacteria that can live in several environmental niches in the rhizosphere. Although, a few Pseudomonas spp. are studied for their role as plant pathogens i.e., Pseudomonas syringae but there are many species such as $P$. fluorescens, $P$. putida, $P$. aeaureofasciens and $P$. chloraphis, which may act as plant beneficial bacteria by antagonizing plant pathogens and through the production of traits that directly influence plant disease resistance and growth (Venturi 2006).

Plant Growth Promoting Rhizobacteria (PGPR $\approx \mathrm{PGPB})$ are natural rhizosphereinhabiting bacteria, which belong to diverse genera such as Pseudomonas and Bacillus species. These microorganisms have been isolated from a wide variety of wild and cultivated plant species such as Arabidopsis, barley, rice, canola and bean (PerselloCartieaux et al., 2003). PGPR are used as inoculants for biofertilization, phytoestimulation and biocontrol. The general effect of PGPR is an increased growth and productivity of plants. Their contribution can be exerted through different mechanisms including root system architecture modulation and increased shoot growth by production of phytohormones such as auxins and cytokinins. Free-living microbes including filamentous fungi of the genus Trichoderma sp. and a variety of plant growth-promoting rhizobacteria (PGPR) are able to suppress soil-borne plant pathogens and to stimulate plant growth by different direct or indirect mechanisms, such as production of phytohormones, mycoparasitism and competence with plant pathogens, decomposition and mineralization of organic matter and enhancing the bioavailability of mineral nutrients such as phosphorus and iron (Valencia et al.,2007).

Oroxylum indicum is a medicinally important forest tree species. This species is categorized as vulnerable due to over exploitation of whole plant for medicinal uses (Ravikumar and Ved 2000; Saraf et al., 2013). Das et al., 2013 reported that $O$. indicum is categorized under endangered status in North east India. Very little information is available on the soil nutrient status and rhizospheric micro biota associated with this medicinal plant species. Quiang (2006) reported that $O$. indicum lives in relationship with the actinomycetePseudonocardia oroxyli present in the soil surrounding the roots. Rashidi and Deokule, (2013) isolated 14 fungal species in the rhizosphere of $O$. indicum which comprised mainly of Fusarium solani, $F$. reticulatum, $F$. equiseti, $F$ oxysporum, $F$. semitectum, $F$. acuminatum, Rhizopus oryzae, A. niger, A. parasiticus, Cunningamella elegans, Syncephalestrum racemosum, Chaetomium indicum, Trichoderma sp. and Papulaspora immerse. In the present study the fungal as well as bacterial microbiota present in the rhizospheric soil sample of $O$. indicum was analysed with respect to the soil nutrient 
status of the tree growing in different natural habitat in North East India. The determination of the soil fungal as well as bacterial community composition along with physicochemical properties of soil is essential in order to evaluate above- and below-ground plant ecosystem health and functioning. It is also a prospective to exploit micro-biota for future conservation strategies.

\section{Materials and Methods}

\section{Collection of the rhizospheric soil, root and plant samples}

The rhizospheric soil and plant samples were collected from five different sites of Northeast India where Oroxylum indicum was naturally growing in its ecological habitat. The rhizospheric soil and root samples and pods were collected from Jorhat, Nalbari, Guwahati, Itanagar and North Lakhimpur. The samples of $O$. indicum were collected from trees showing fruiting from five different collection sites of a single ecoregion (Brahmaputra Valley semi- evergreen forests), i.e. Jorhat, Nalbari, Guwahati, Itanagar and North Lakhimpur. Rhizospheric soil samples along with root segments were taken by digging out a small amount of soil (500g) close to the plant roots up to a depth $15-30 \mathrm{~cm}$ and these samples were kept in sterilized polythene bags for further processing in the laboratory for physicochemical analysis of soil, mycorrhizal colonization and spore quantification etc. Samples from the selected plant species were collected from the plant growing along riverside in Nalbari. From Guwahati, samples were collected from the tree growing in forest fringe area. Samples from hill slope were collected from Itanagar, while, sample from agricultural farmland were collected from North Lakhimpur. The samples were collected from healthy trees which overall represented the region.

\section{Isolation of fungal isolates}

The rhizospheric soil samples were collected from five different study sites in polyethene bags and was further analysed in the laboratory. Soil Dilution Plate Method (Waksman 1927) was used for the isolation of fungal species. Soil dilutions were made by suspending $1 \mathrm{~g}$ of soil of each sample in $10 \mathrm{ml}$ of sterile distilled water. Dilutions of $10^{-2}, 10^{-}$ 3 and $10^{-4}$ were used to isolate fungi in order to avoid over-crowding of the fungal colonies. $1 \mathrm{ml}$ of the suspension of each concentration was added to sterile Petri dishes, in triplicates of each dilution, containing sterile Potato Dextrose Agar (PDA) medium. 1\% streptomycin solution was added to the medium for preventing bacterial growth, before pouring into Petri plates. The plates were then incubated at $28 \pm 2{ }^{\circ} \mathrm{C}$ for $4-7$ days. Fungi easily isolated because they formed surface colonies that were well dispersed particularly at higher dilutions. The pure colonies were preserved in PDA slants and stored at $3-4^{\circ} \mathrm{C}$ for further analysis.

\section{Identification of the soil fungi}

Identification of the fungal species is based on morphological characteristics of the colony and microscopic examinations (Diba et al., 2007). The fungi were identified by the help of various taxonomic keys available (Gilman 1957; Subramanian, 1971; Watanabe 1993; Domsch et al., 2007; Singh et al., 1991).

\section{Isolation of bacterial isolates}

The isolation of soil bacteria was done by using dilution plate technique as given by Johnson and Curl (1972) at $10^{6}$ dilutions on Nutrient Agar (NA). The NA plates were incubated at $30 \pm 1^{\circ} \mathrm{C}$ for 48 hours. The pure cultures of bacteria were preserved at $4^{0} \mathrm{C}$ in NA slants after observing the abundance of bacterial growth and colony morphology. The 
isolated bacteria were preserved in $15 \%(\mathrm{v} / \mathrm{v})$ glycerol in nutrient broth (NB) at $-20^{\circ} \mathrm{C}$.

\section{Identification of bacterial isolates}

The identification of bacteria is based on external morphology as well as biochemical tests. The physiological and biochemical characteristics were examined according to Cappuccino and Sherman (2004) and Bergey's Manual of Systematic Bacteriology, 1934. In order to differentiate Gram-positive and Gram- negative strain of bacteria, a modified method of Gram staining (Cruickshank, 1965) was followed.

The soil samples were analysed in the laboratory of Rain Forest Research Institute, Jorhat following standard methods. Soil $\mathrm{pH}$ was determined by the help of standard $\mathrm{pH}$ meter. The soil Organic Carbon Estimation was done by Walkley-Black's method (1934). The estimation of Available Nitrogen in soil was done with the help of Kjeldahl (1883). The estimation of available Potassium in soil was done through Ammonium acetate extraction method by R.R. Simard (1993). Soil Available Phosphorus estimation was done according to Bray (1948).

Results of the various experiments were analyzed following appropriate statistical methods as per the procedure suggested by Panse and Sukhatme (1978). The results were further analysed using IBM SPSS Statistics 21. The ANOVA as well as DMRT was applied on the data sets.

\section{Results and Discussion}

The rhizospheric samples of Oroxylum indicum were collected from five different collection sites of a single eco-region of Northeast India (Brahmaputra Valley semievergreen forests), i.e. Jorhat, Nalbari, Guwahati, Itanagar and North Lakhimpur. In
Jorhat the sampling was done along roadside, while, in Nalbari, the sampling was done along riverside. The samples were collected from forest fringe zone in Guwahati collection site, while, soil samples from hill slope were collected from Itanagar site. In North Lakhimpur site the soil samples were collected from agricultural farmland. The highest elevation was observed in Itanagar while lowest was found in Nalbari. Table 1 shows the $\mathrm{pH}$ and nutrient status of the soil under naturally growing $O$. indicum tree species. The organic carbon content \%, available Nitrogen ( $\mathrm{kg} / \mathrm{hac})$, available Potassium and available Phosphorus (P) in $\mathrm{kg} / \mathrm{hac}$ was determined. The nutrient status of soil varied along different collection sites. The soil status of the sample collected from Jorhat site has a $\mathrm{pH}$ value ranging between $5.89 \pm 0.11$ to $6.2 \pm 0.03$. The soil organic carbon percentage varied between $1.243 \pm 0.034$ to $1.282 \pm 0.025$, available Nitrogen $(\mathrm{kg} / \mathrm{hac})$ ranged between $242.69 \pm 0.001$ to $301.27 \pm 0.001$, and available Phosphorus $(\mathrm{kg} / \mathrm{hac})$ varied between $34.39 \pm 2.90$ to $39 \pm 3.151$, while available potassium $(\mathrm{kg} / \mathrm{hac})$ varied between $28.52 \pm 0.754$ to $37.36 \pm 1.24$. In Nalbari site the $\mathrm{pH}$ of the soil varied from $5.91 \pm 0.11$ to $6.11 \pm 0.08$. The organic carbon percentage was found to range between $1.320 \pm 0.033$ to $1.397 \pm 0.034$, the available nitrogen $(\mathrm{kg} / \mathrm{hac})$ varied between $326.37 \pm 0.002$ to $359.85 \pm 0.002$; available phosphorus $(\mathrm{kg} / \mathrm{hac})$ was between $40.78 \pm 3.15$ to $43.61 \pm 0.81$ and available potassium varied between $21.39 \pm 1.78$ to $25.09 \pm 1.58$. In Guwahati site the $\mathrm{pH}$ varied between $5.25 \pm 0.187$ to $5.61 \pm 0.097$, the organic carbon ranged between $1.760 \pm 0.050$ to $1.808 \pm 0.033$. The available nitrogen $(\mathrm{kg} / \mathrm{hac})$ varied between $175.74 \pm 0.0006$ to $217.58 \pm 0.001$; available phosphorus $(\mathrm{kg} / \mathrm{hac})$ was between $38.82 \pm 0.614$ to $41.8 \pm 0.063$ and available potassium varied between $29.37 \pm 1.24$ to $36.22 \pm 1.02$. The soil nutrient status of 
Itanagar site shows that the $\mathrm{pH}$ varied between $5.17 \pm 0.323$ to $5.47 \pm 0.279$, The organic carbon percentage was found to be $1.081 \pm 0.078$, the available nitrogen $(\mathrm{kg} / \mathrm{hac})$ varied between 472.82 \pm 0.001 to $564.88 \pm 0.001$, available phosphorus ( $\mathrm{kg} / \mathrm{hac})$ was between $44.32 \pm 1.799$ to $46.27 \pm 0.307$ and available potassium varied between $42.49 \pm 1.50$ to $45.34 \pm 1.48$. In North Lakhimpur site the $\mathrm{pH}$ of the soil varied from $5.38 \pm 0.43$ to $6.05 \pm 0.131$. The organic carbon percentage was found to range between $1.808 \pm 0.033$ to $1.865 \pm 0.049$, the available nitrogen $(\mathrm{kg} / \mathrm{hac}) \quad$ varied between $594.17 \pm 0.003$ to $648.56 \pm 0.004$, available phosphorus (kg/hac) was between $48.22 \pm 0.639$ to $50.17 \pm 0.639$ and available potassium varied between $45.06 \pm 1.99$ to $49.34 \pm 1.50$. The DMRT analysis of different parameters was done to segregate different parameters. The DMRT analysis of the $\mathrm{pH}$ status was higher in Jorhat and Nalbari, intermediate $\mathrm{pH}$ was found in North Lakhimpur site while mimum $\mathrm{pH}$ was found in Guwahati and Itanagar site. Overall, the $\mathrm{pH}$ of the soil under $O$. indicum is acidic. The \% Organic Carbon was found to be highest in North Lakhimpur site while it was lowest in Itanagar site. Available Nitrogen was highest in NorthLakhimpur, while it was minimum in Guwahati. Available Phosphorus was again highest in North Lakhimpur site while it was lowest in Nalbari and Guwahati site. Available Potassium was highest in Itanagar and North Lakhimpur sites while it was lowest in Nalbari site. Soil borne microorganisms are beneficial for plant growth.

Rhizospheric mycoflora associated with the rhizospheric soil samples of Oroxylum indicum (L.) Benth. ex Kurz

The natural occurrence of the mycoflora associated in the rhizosphere of O.indicum was assessed in the laboratory of RFRI, Jorhat. The rhizospheric samples of $O$. indicum were collected from five different collection sites i.e. Jorhat, Nalbari, Guwahati, Itanagar and North Lakhimpur. 25 fungal species were isolated from the rhizosphere of $O$. indicum (Table 5). A total of 11 fungal species were isolated from the Jorhat collection site, which comprised mainly of Trichoderma harzianum, Penicillium sp., Aspergillus sp., Trichoderma viride, Fusarium sp., Penicillium funiculosum, Penicillium capsulatum, Penicillium citrinum, Pachybasium sp., Trichoderma hamatum, Mucor sp. 12 fungal species were isolated from the rhizosphere of $O$. indicum from Nalbari collection site i.e. Trichoderma harzianum, Penicillium sp., Aspergillus sp., Verticillium sp., Fusarium sp., Curvularia sp., Penicillium capsulatum, Rhizomucor sp., Pythium sp., Penicillium citrinum, Pachybasium sp, Penicillium sp. The Guwahati collection site showed occurrence of 14 fungal isolates i.e. Rhizoctonia sp., Trichoderma harzianum, Penicillium sp., Colletrotrichum sp., Geotrichum sp., Trichoderma viride, Trichoderma hamatum, Penicillium capsulatum, Cunnighamella sp., Pythium sp., Penicillium citrinum, Pachybasium sp., Mucor sp., Trichoderma sp.

A total of 12 fungal species were isolated from the Itanagar collection site, which mainly comprised of Rhizoctonia sp., Trichoderma harzianum, Trichoderma viride, Scelosporium sp., Absidia sp., Fusarium sp., Colletrotrichum sp., Curvularia sp., Mucor sp., Pythium sp., Pachybasium sp. The North Lakhimpur collection site showed the occurrence of 15 fungal isolates which mainly comprised of Rhizoctonia sp., Trichoderma harzianum, Aspergillus sp., Trichoderma viride, Absidia sp., Fusarium sp., Trichoderma hamatum, Gliocladium sp., Colletrotrichum sp., Rhizoctonia solani, Penicillium capsulatum, Rhizomucor sp., Pythium sp., Penicillium citrinum, Pachybasium sp. only (Plate 1.1 and 1.2). 
Table.1 Soil status of different collection sites of Oroxylum indicum (L.) Benth. ex Kurz

\begin{tabular}{|c|c|c|c|c|c|c|}
\hline Sample & Habitat & pH & $\% \mathrm{OC}$ & Available N (kg/hac) & Avl P (kg/hac) & Avl K (kg/hac) \\
\hline \multirow{3}{*}{ JORHAT } & \multirow{3}{*}{ Roadside } & $5.89 \pm 0.11$ & $1.282 \pm 0.025$ & $242.69 \pm 0.001$ & $39 \pm 3.151$ & $36.506 \pm 1.73$ \\
\hline & & $6.2 \pm 0.03$ & $1.243 \pm 0.034$ & $251.05 \pm 0.002$ & $34.39 \pm 2.90$ & $28.52 \pm 0.754$ \\
\hline & & $5.74 \pm 0.141$ & $1.253 \pm 0.025$ & $301.27 \pm 0.001$ & $34.75 \pm 5.22$ & $37.36 \pm 1.24$ \\
\hline \multirow{3}{*}{ NALBARI } & \multirow{3}{*}{ Riverside } & $6 \pm 0.173$ & $1.339 \pm 0.025$ & $330.56 \pm 0.001$ & $40.78 \pm 3.15$ & $21.39 \pm 1.78$ \\
\hline & & $6.11 \pm 0.08$ & $1.397 \pm 0.034$ & $326.37 \pm 0.002$ & $41.48 \pm 1.91$ & $24.81 \pm 1.30$ \\
\hline & & $5.91 \pm 0.11$ & $1.320 \pm 0.033$ & $359.85 \pm 0.002$ & $43.61 \pm 0.81$ & $25.09 \pm 1.58$ \\
\hline \multirow{3}{*}{ GUWAHATI } & \multirow{3}{*}{$\begin{array}{l}\text { Forest } \\
\text { Fringe }\end{array}$} & $5.4 \pm 0.221$ & $1.760 \pm 0.050$ & $209.21 \pm 0.008$ & $41.8 \pm 0.063$ & $36.22 \pm 1.02$ \\
\hline & & $5.25 \pm 0.187$ & $1.760 \pm 0.074$ & $175.74 \pm 0.0006$ & $39.71 \pm 0.987$ & $29.37 \pm 1.24$ \\
\hline & & $5.61 \pm 0.097$ & $1.808 \pm 0.033$ & $217.58 \pm 0.001$ & $38.82 \pm 0.614$ & $34.79 \pm 1.99$ \\
\hline \multirow{3}{*}{ ITANAGAR } & \multirow{3}{*}{ Hill Slope } & $5.41 \pm 0.270$ & $1.081 \pm 0.050$ & $472.82 \pm 0.001$ & $45.92 \pm 0.639$ & $43.92 \pm 1.73$ \\
\hline & & $5.47 \pm 0.279$ & $1.081 \pm 0.078$ & $502.11 \pm 0.001$ & $44.32 \pm 1.799$ & $45.34 \pm 1.48$ \\
\hline & & $5.17 \pm 0.323$ & $1.081 \pm 0.058$ & $564.88 \pm 0.001$ & $46.27 \pm 0.307$ & $42.49 \pm 1.50$ \\
\hline \multirow{3}{*}{$\begin{array}{l}\text { NORTH } \\
\text { LAKHIMPUR }\end{array}$} & \multirow{3}{*}{$\begin{array}{l}\text { Agricultural } \\
\text { Farmland }\end{array}$} & $5.65 \pm 0.174$ & $1.808 \pm 0.033$ & $594.17 \pm 0.003$ & $48.22 \pm 0.639$ & $49.34 \pm 1.50$ \\
\hline & & $6.05 \pm 0.131$ & $1.846 \pm 0.041$ & $648.56 \pm 0.004$ & $50.17 \pm 0.639$ & $45.63 \pm 0.75$ \\
\hline & & $5.38 \pm 0.43$ & $1.865 \pm 0.049$ & $623.46 \pm 0.001$ & $48.58 \pm 0.639$ & $45.06 \pm 1.99$ \\
\hline
\end{tabular}

Table.2 Bacteria in rhizosphere of Oroxylum indicum (L.) Benth. ex Kurz

\begin{tabular}{|l|c|c|c|c|c|}
\hline \multicolumn{1}{|c|}{ Bacteria } & Jorhat & Nalbari & Guwahati & Itanagar & N. Lakhimpur \\
\hline Pseudomonas putida & + & + & + & - & + \\
\hline Pseudomonas sp. & + & - & + & - & + \\
\hline Streptobacillus sp. & - & + & + & + & - \\
\hline Bacillus sp. & + & - & + & + & + \\
\hline
\end{tabular}

+ denotes present, - denotes absent.

Table.3 Classification of bacteria based on colony morphology

\begin{tabular}{|c|l|c|c|}
\hline Sl.No. & Biochemical test & Pseudomonas species & Bacillus species \\
\hline 1 & Gram stain & - & + \\
\hline 2 & Shape & Rod & Rod \\
\hline 3 & Agar plate character & White translucent (Kings B medium) & Dull white \\
\hline 4 & Methyl red test & - & - \\
\hline 5 & Catalase test & + & + \\
\hline 6 & Oxidase test & + & + \\
\hline 7 & Growth in NB & - & + \\
\hline 8 & Glucose fermentation test & - & + \\
\hline 9 & Nitrate reduction test & & NA \\
\hline
\end{tabular}

Table.4 Biochemical test of bacteria

\begin{tabular}{|l|l|l|l|}
\hline \multicolumn{1}{|c|}{ Species } & \multicolumn{1}{|c|}{ Colony morphology } & $\begin{array}{c}\text { Gram's } \\
\text { reaction }\end{array}$ & Cell shape \\
\hline Streptobacillus sp. & $\begin{array}{l}|c| \\
\text { sweomorphic, Fusiform; develop characteristic lateral bulbar }\end{array}$ & Gram -ve & Rods \\
\hline Pseudomonas putida & Round, Translucent whitish, Bright, Button shaped Colonies & Gram -ve & Rods \\
\hline Bacillus sp. 1 & Punctiform, Irregular, Opaque, Whitish, Raised & Gram +ve & Rods \\
\hline Pseudomonas sp. & Irregular, whitish, raised colonies & Gram -ve & Rods \\
\hline
\end{tabular}


Table.5 Rhizospheric mycoflora associated with Oroxylum indicum (L.) Benth. ex Kurz

\begin{tabular}{|c|c|c|c|c|c|c|c|}
\hline Sl. No. & Fungal Species & Family & Jorhat & Nalbari & Guwahati & Itanagar & N. Lakhimpur \\
\hline 1. & Absidia $\mathrm{sp}$ & Cunnighamellaceae & - & - & - & + & + \\
\hline 2. & Aspergillus sp. & Trichocomaceae & + & + & - & + & + \\
\hline 3. & Colletrotrichum sp. & Glomerellaceae & - & - & + & + & + \\
\hline 4. & Cunnighamella sp. & Cunnighamellaceae & - & & + & - & - \\
\hline 5. & Curvularia sp. & Pleosporaceae & - & + & - & + & - \\
\hline 6. & Fusarium sp. & Nectriaceae & + & + & - & + & + \\
\hline 7. & Geotrichum sp. & Endomycetaceae & - & - & + & - & - \\
\hline 8. & Gliocladium sp. & Hypocreaceae & - & - & - & - & + \\
\hline 9. & Mucor sp. & Mucoraceae & + & - & + & + & - \\
\hline 10. & Pachybasium sp. & Hypocreaceae & + & + & + & + & + \\
\hline 11. & Penicillium capsulatum Raper and Fennell & Trichocomaceae & + & + & + & - & + \\
\hline 12. & Penicillium citrinum Thom & Trichocomaceae & + & + & + & - & - \\
\hline 13. & Penicillium funiculosum Thom & Trichocomaceae & + & - & - & - & - \\
\hline 14. & Penicillium sp. 1 & Trichocomaceae & + & + & + & - & + \\
\hline 15. & Penicillium sp. 2 & Trichocomaceae & - & + & - & - & - \\
\hline 16. & Pythium sp. & Pythiaceae & - & + & + & + & + \\
\hline 17. & Rhizoctonia solani Kuhn. & Ceratobasidiaceae & - & - & - & - & + \\
\hline 18. & Rhizoctonia sp. & Ceratobasidiaceae & - & & + & + & + \\
\hline 19. & Rhizomucor sp. & Mucoraceae & - & + & - & - & + \\
\hline 20. & Scedosporium sp. & Microascaceae & - & - & -- & + & - \\
\hline 21. & Trichoderma hamatum (Bonord.) & Hypocreaceae & + & - & + & - & + \\
\hline 22. & Trichoderma harzianum Pers. & Hypocreaceae & + & + & + & + & + \\
\hline 23. & Trichoderma sp. & Hypocreaceae & - & - & + & - & - \\
\hline 24. & Trichoderma viridae Pers. & Hypocreaceae & + & - & + & + & + \\
\hline 25. & Verticillium sp.(Nees) & Plectospharellaceae & - & + & - & - & - \\
\hline
\end{tabular}

+ denotes present, - denotes absent 
Plate.1 A. Aspergillus ruber B. Trichoderma harzianum C. Penicillium citrinum D. Aspergillus sp. E. Absidia sp. F. Penicillium funniculosum G. Rhizoctonia solanii H. Penicillium capsulatum I. Aspergillus sp. J.Cunnighamella sp. K. Mucor sp. L. Aspergillus sp.
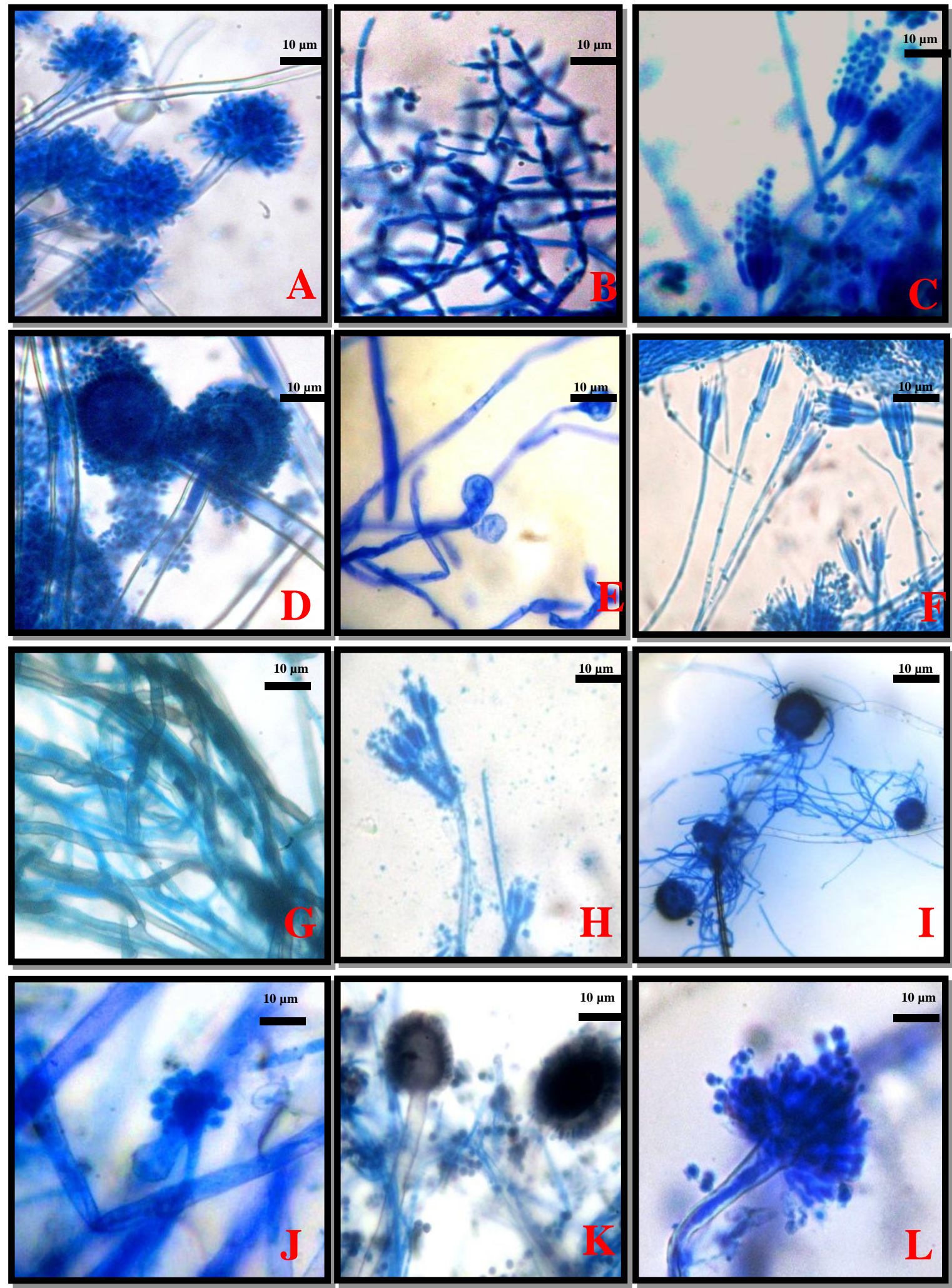
Plate.2 Isolation of fungal species from rhizospheric soil samples A. Jorhat site B. and C. Nalbari site D. Guwahati site E. Itanagar site F. and G. North Lakhimpur site H., I., J. and K. Isolation of fungal species at different dilutions L. Pure culture of Trichoderma harzianum
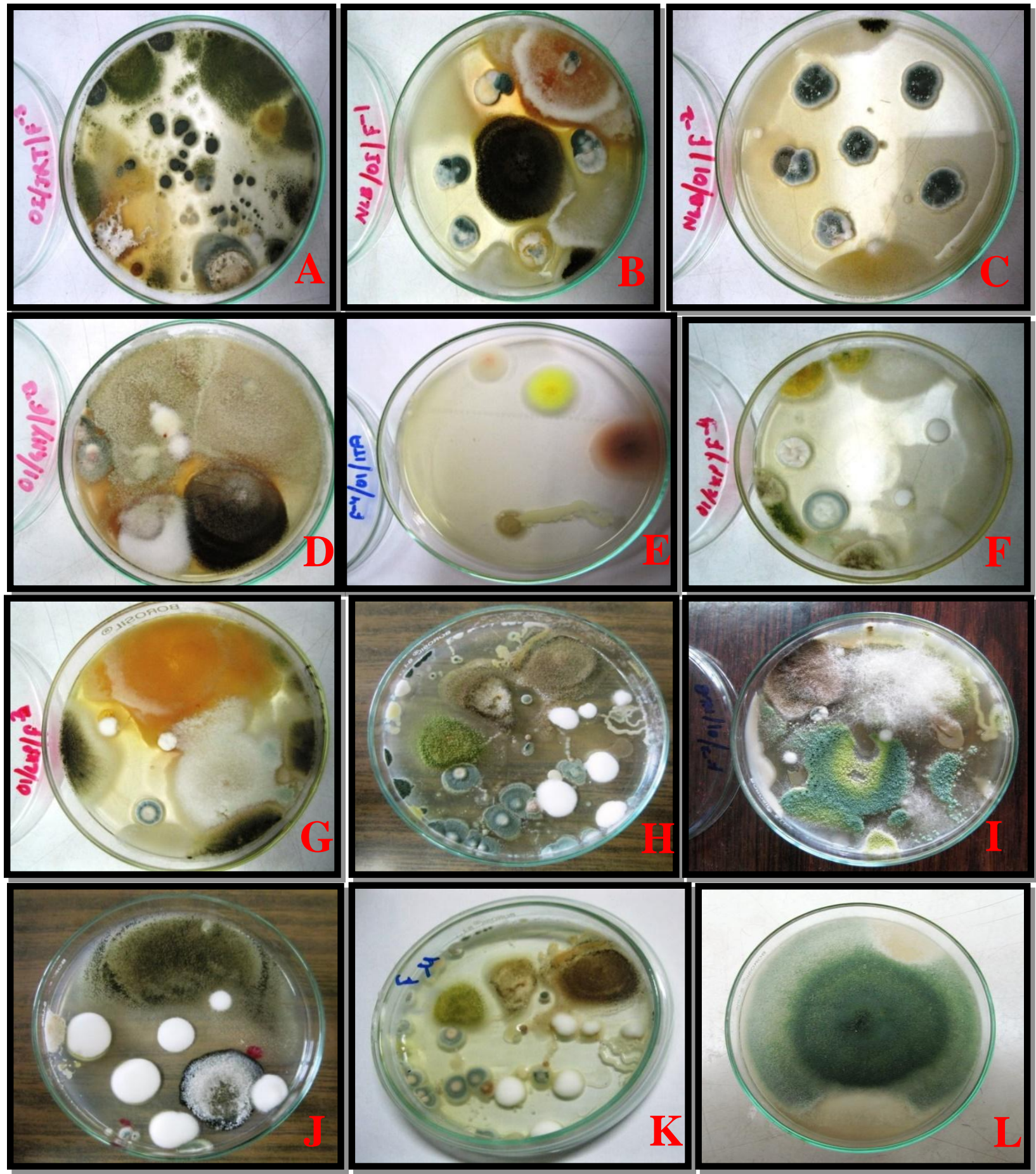
Plate.3 A: Pseudomonas sp., B: Pseudomonas putida C: Bacillus sp. D: Streptobacillus sp. E-G: Culturing and subculturing of the bacterial species

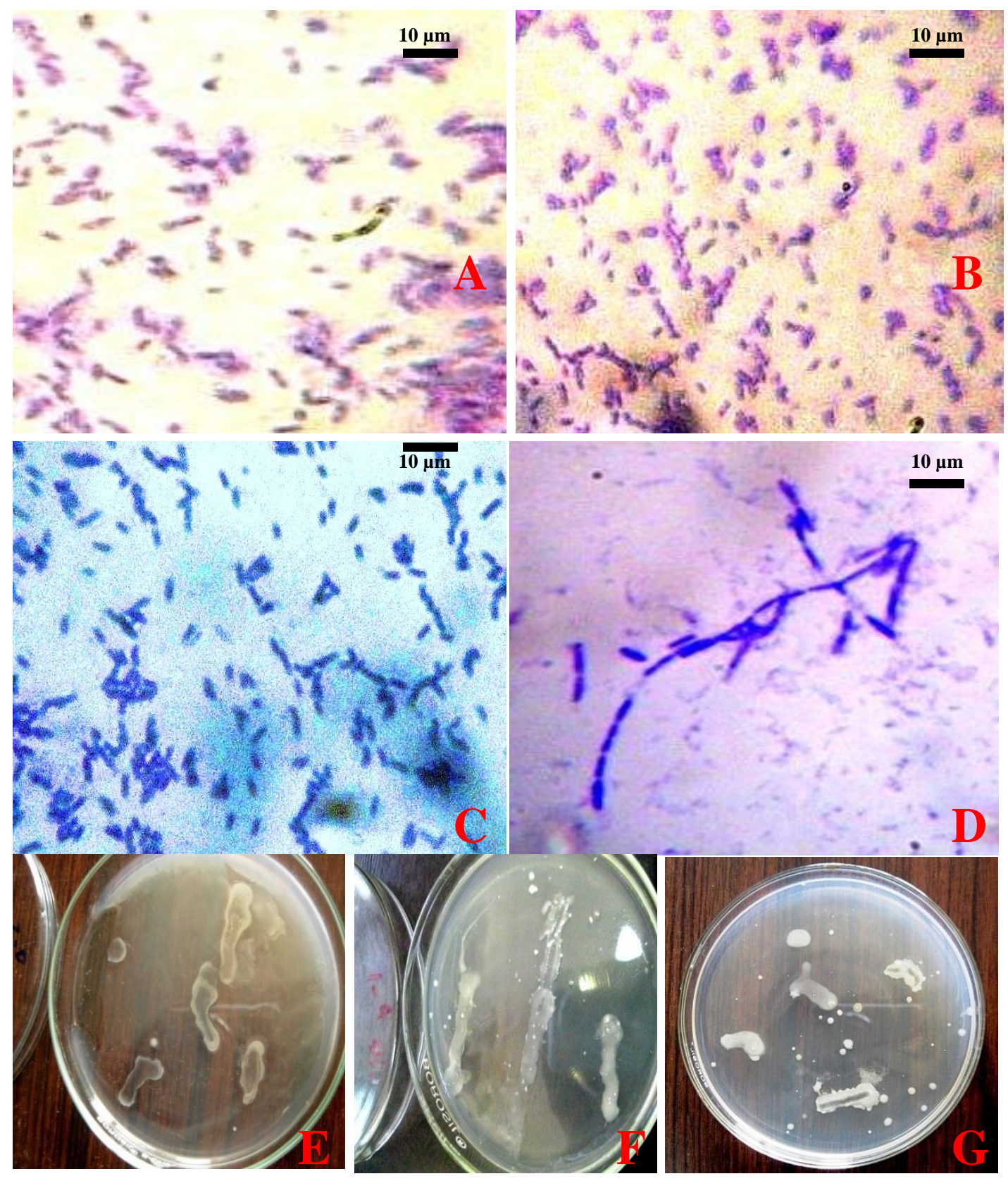

Four bacterial isolates Pseudomonas putida, Pseudomonas sp., Streptobacillus sp., Bacillus sp. were found to be associated in the rhizosphere of $O$. indicum. Table 2, 3 and 4 shows the bacterial species associated in the rhizospheric soil samples of $O$. indicum, classification and biochemical test performed.
Four bacterial isolates Pseudomonas putida, Pseudomonas sp., Streptobacillus sp., Bacillus sp. were found to be associated in the rhizosphere of $O$. indicum (Plate 1.3). Soil microbes act as essential component of plant community variety and productivity (Wardle 2004). The environmental factors such as the 
soil pH, moisture, temperature, organic carbon and nitrogen play an important role in the distribution of microorganisms (Gaddeyya, 2012). These are the main factors affecting the microbial population and diversity.

The role of fungi in soil is extremely complex and is fundamental to the soil ecosystem (Bridge and Spooner, 2001). Soil fungi play an important role in nutrient cycling, and plant health and development (Bridge and Spooner, 2001; Thorn, 1997; Martin et al., 2001). Some fungi cause a range of plant diseases (Jarosz and Davelos, 1995; Thorn, 1997), while others antagonize plant pathogens, decompose plant residues, provide nutrients to plants, and stimulate plant growth (Raaijmakers et al., 2009). Information on the knowledge of the diversity and structure of fungal communities in bulk and rhizosphere soils help in better understanding of their roles in soil ecosystem and in improving plant health. The activity and effects of beneficial rhizospheric myco-biota on plant growth and health are well documented for fungi under Deuteromycetes e.g. Trichoderma, Gliocladium and non-pathogenic Fusarium species (Raaijmakers et al., 2009).

Direct rhizospheric bio-control effects on soilborne plant pathogens can result from hyperparasitism as is documented for Trichoderma and Gliocladium and it affects various fungal pathogens such as Rhizoctonia, Sclerotinia, Verticillium and Gaeumannomyces (Harman et al., 2004). Thus, determination of the microbiota along with physico-chemical properties of soil associated with rhizosphere of $O$. indicum is essential in order to evaluate above- and below-ground plant ecosystem health and functioning. It is also a prospective to exploit myco-biota for future conservation strategies. Rashidi and Deokule (2013) isolated 14 fungal species in the rhizosphere of $O$. indicum which comprised mainly of Fusarium solani, $F$. reticulatum, $F$. equiseti, $F$. oxysporum, $F$. semitectum, $F$. acuminatum, Rhizopus oryzae, A. niger, A. parasiticus, Cunningamella elegans, Syncephalestrum racemosum, Chaetomium indicum, Trichoderma sp. and Papulaspora immerse.

In the present study 25 fungal species were isolated from the rhizosphere of $O$. indicum. growing under different natural habitat which comprised of Trichoderma sp., Fusarium sp., Cunningamella sp., Aspergillus sp., Penicillium funiculosum, Penicillium capsulatum, Penicillium citrinum, Pachybasium sp., Trichoderma hamatum, Mucor sp., Pythium sp., Penicillium citrinum etc. Curvularia sp. was isolated from the seeds of $O$. indicum which might be the causative agent for fungal decay of seeds. Pande and Gupta (2011) also reported the presence of Curvularia lunata as seed mycoflora of $O$. indicum.

The study of rhizosphere bacteria from the important medicinal plants is very crucial, as they are known to have impact on plant growth and also produce industrially important metabolites and improve quality of medicinal product (Bafana and Lohiya, 2013). The rhizospheric soil samples of this plant species mainly comprised of Pseudomonas putida, Pseudomonas sp. and Bacillus sp and Streptobacillus sp. A significant number of bacteria produce the phytotherapeutic compounds (Koeberl et al., 2013) and increase the growth of the medicinal plants when they are associated with rhizosphere of plants.

The study revealed that rhizospheric soil of Oroxylum reflects the presence of diverse fungi and bacteria. Concerned study are to be taken up to conserve the target plant species by modern biotechnological eco-friendly methods and to produce healthy and quality stock of superior germplasm. 


\section{Acknowledgement}

Authors are thankful to Rain Forest Research Institute (Indian council of Forestry Research and Education), Jorhat, Assam for providing the all possible laboratory facilities and experimental field for carrying out the research work.

\section{References}

Badri, D.V., Quintana, N., El Kassis, E.G., Kim, H.K., Choi, Y.H. and Sugiyama, A. 2009. An ABC transporter mutation alters root exudation of phytochemicals that provoke an overhaul of natural soil microbiota. Plant Physiology, 151: 2006-2017.

Bafana, A. and Lohiya, R. 2013. Diversity and metabolic potential of culturable root-associated bacteria from Origanum vulgare in sub-Himalayan region. World Journal of Microbiology and Biotechnology, 29:63-74.

Berg, G. and Smalla, K. 2009. Plant species and soil type cooperatively shape the structure and function of microbial communities in the rhizosphere. FEMS Microbiology Ecology, 68:1-13.

Bergey, D.H., Breed, R.S., Murray, E.G.D.and Harrison, F.C (eds.). 1934. Bergey's manual of systematic bacteriology. International journal of systematic bacteriology, p.408.

Bray, R.H. 1948. Correlation of soil tests with crop response to fertilizers and with fertilizer requirement. In: Kitchen H.B. (ed.). Diagnostic techniques for soils and crops. American Potash Institute, Washington D.C.

Bridge, P., Spooner, B.M. 2001. Soil fungi: diversity and detection. Plant and Soil, 232:147-154.

Broeckling, C.D., Broz, A.K., Bergelson, J., Manter, D.K. and Vivanco, J.M. 2008. Root exudates regulate soil fungal community composition and diversity. Applied. Envronmental Microbiology, 74(3): 738-744.

Cappuccino, J.G. and Sherman, N.2004. Microbiology: A laboratory manual, $6^{\text {th }}$ ed, Pearson education Pvt. Ltd. 482, New Delhi. Pp. 143-153, 1554-1556, 167, 181-185.

Cruickshank, J.A.M. 1965. In: Ecology of soil borne pathogens. Prelude to biological control. Pp. 325.

Das, A.J., Kumar, R., Athar, M., Rawat, D.S., Kumar, M., Khan, M.A., and Prakash, J. 2013. Ethno medicinal study of threatened plants of Sonitpur district in Assam, North east India.

Diba, K., Kordbacheh, P., Mirhendi, S.H., Rezaie, S. and Mahmoudi, M. 2007. Identification of Aspergillus sp. using morphological characters. Pakistan Journal of Medical Science, 23:867872.

Domsch, K.H., Gams, W. and Anderson, T. 2007. Compendium of soil fungi.2 nd Edition. IHW Verlag. Eching, Germany.

Gaddeyya, G., Shiny, N.P, Bharathi, P., and Kumar, P.K. 2012. Isolation and Identification of soil mycoflora in different crop fields at salur mandal. Advances in Applied Science Research, 3(4): 2020- 2026.

Gilman, J.C. 1957. A manual of soil fungi, Iowa State College Press.

Harman, G.E., Petzoldt, R., Comis, A. and Chen, J. 2004. Interactions between Trichoderma harzianum strain T22 and maize inbred line Mo17 and effects of these interactions on diseases caused by Pythium ultimum and, Colletotrichum graminicola. Phytopathology, 94: 147153.

Jarosz, A.M., Davelos, A.L. 1995. Effects of disease in wild plant populations and the evolution of pathogen aggressiveness. New Phytologist 129, 371-387 
Johnson, L.F. and Curl, E.A. 1972. Methods for research on the ecology of soilborne plant pathogens. 426 So. Sixth St. Minneapolis, Burgess.

Kjeldahl, J. 1883. A new method for the estimation of organic compounds. $\mathrm{Z}$. Anal. Chem., 22, 366.

Koeberl, M., Schmidt, R., Ramadan, E.M., Bauer, R., and Berg, G. 2013. The microbiome of medicinal plants: diversity and importance for plant growth, quality, and health. Frontiers in Microbiology, 4: 400.

Martin, F.M., Perotto, S., Bonfante, P. 2001. Mycorrhizal fungi. In: The Rhizosphere - a fungal community at the interphase between soil and roots (eds R Pinton, Z Varanini, P Nannipieri). New York, Marcel Dekker, 263-296.

Pande, B.J. and Gupta, R.C.2011. Role of seed mycoflora on seed germination of Oroxylum indicum (L.) Vent. In Kumaun region of Indian Central Himalaya. International Journal of Biodiversity and Conservation, 3(13):715-720.

Panse, V.G. and Sukhatme, P.V. 1978. Statistical methods for Agricultural Workers. Indian Council of Agricultural Research, New Delhi, pp: 136.

Persello-Cartieaux, F., Nussaume, L. and Robaglia, C. 2003. Tales from the underground: molecular plantrhizobacteria interactions. Plant Cell and Environment, 26: 189-199.

Qiang, G., Luo, H., Zheng, W, Liu, Z., and Huang, Y. 2006. Pseudonocardia oroxyli sp. nov., a novel actinomycete isolated from surface-sterilized Oroxylum indicum root. International Journal of Systematic and Evolutionary Microbiology, 56: 2193-7.

Raaijmakers, J.M., Paulitz, T.C., Steinberg, C., Alabouvette, C., Moënne-Loccoz, Y.2009. The rhizosphere: a playground and battlefield for soilborne pathogens and beneficial microorganisms. Plant Soil, 321, 341-361.

Rashidi, M. and Deokule, S.S. 2013. Fungal association and deterioration of chemical constituents of Oroxylum indicum (vent.) roots under the influence of relative humidity. International Journal of Pharmaceutical and Phytopharmacological Research, 2(3):1 90.

Ravikumar, K, and Ved, D.K. 2000. 100 Red listed medicinal plants of conservation concern in Southern India. Foundation for Revitalization of Local Health Traditions, Bangalore. India.

Ryan, P.R. and Delhaize, E. 2001 Function and mechanism of organic anion exudation from plant roots. Annual Review of Plant Physiology and Molecular Biology, 52:527-560.

Saraf, A., Srinivas, S. and Labhane, N.M. 2013. Pharmacognostic studies and HPTLC finger print profile of stem of Oroxylum indicum (L) Vent: a threatened and vulnerable medicinal plant. Research Journal of Pharmaceutical, Biological and Chemical Sciences, 4 (3): 1078-1084.

Simard, R. R.1993. Ammonium acetate extractable elements. In: Soil sampling and methods of analysis. Martin, R and Carter S (eds). Lewis publishers, Florida, 39-43.

Singh, K., Frisvad, J.C., Thrane, U. and Mathur, S.B. 1991. An illustrated manual on the identification of some seed- borne Aspergilli, Fusaria, Penicillia and their mycotoxins. Lyngby, Denmark.

Subramanian, C.V.1971. Hyphomycetes: An account of Indian species except Cercosporae. ICAR, New Delhi

Thorn, G. 1997. The fungi in soil. In: Modern Soil Microbiology (eds JD van Elsas, JT Trevors, EMH Wellington). New York, 
Marcel Dekker 63-127.

Valencia, E., Radhika, L.G., Meena, C.V., Peter, S., Rajesh, K.S. and Rosamma, M.P. 2011. Phytochemical and antimicrobial study of Oroxylum indicum. Ancient Science Life, 30: 114120.

Venturi, V. 2006. Regulation of quorum sensing in Pseudomonas. FEMS Microbiology Review, 30: 274-291.

Waksman, S.A. 1927. Principle of Soil Microbiology, Williams and Wilkins, Baltimore, Md, USA.

Walkley, A. and Black, I.A. 1934. An examination of the Degtjareff method for determining soil organic matter, and a proposed modification of the chromic acid titration method. Soil Science, 34:29-38.

Wardle, D.A., Bardgett, R.D., Klironomos, J.N., Setala, H., Van der Putten, W.H., and Wall, D.H. 2004. Ecological linkages between above ground and below ground biota. Science, 304 (11): 1629-1633.

Watanabe, T. 1993. Photomicrographs and illustrations of soil fungi. Soft Science Publications. Tokyo.

\section{How to cite this article:}

Chandrima Debi and Vipin Parkash. 2017. Comparative Soil Nutrient Status and Microbiota Associated in the Rhizosphere of Oroxylum indicum growing in Different Natural Habitat in North East India. Int.J.Curr.Microbiol.App.Sci. 6(12): 2627-2640. doi: https://doi.org/10.20546/ijcmas.2017.612.304 